\title{
Planning Project Stakeholder Engagement from a Sustainable Development Perspective
}

\author{
Gilbert Silvius ${ }^{1,2, *(1)}$ and Ron Schipper ${ }^{3}$ \\ 1 Research Group Project Management, LOI University of Applied Sciences, Leidsedreef 2, 2352 BA \\ Leiderdorp, The Netherlands \\ 2 College of Business and Economics, University of Johannesburg, Kingsway Avenue, Johannesburg 2006, \\ South Africa \\ 3 P2 Management Consultants, Slotselaan 6-8, 5328 ER Rossum, The Netherlands; rpj.schipper@gmail.com \\ * Correspondence: mail@gilbertsilvius.nl
}

Received: 28 February 2019; Accepted: 20 June 2019; Published: 24 June 2019

check for updates

\begin{abstract}
Sustainability is one of the most important challenges of our time. As the role that projects play in sustainable development is still developing, the integration of the concepts of sustainability into project management is an important trend in project management today. However, despite the conceptual understanding of this integration, the literature still provides little practical guidance on how to apply sustainability to project management. This article aims to contribute to the integration of sustainable development and project stakeholder management by developing practical tools and frameworks that enable project managers to identify stakeholders, assess stakeholders, and plan stakeholder engagement activities with a consideration of sustainable development. The study takes a pragmatic design science approach in developing these tools and frameworks. The resulting frameworks build upon the concepts of sustainable development and form an elaboration of the documented practices of project stakeholder management.
\end{abstract}

Keywords: sustainable project management; stakeholders; project stakeholder management

\section{Introduction}

Sustainability is one of the most important challenges of our time. How can we develop prosperity without compromising the lives of future generations? Senior business professionals acknowledge that "business will need to play the leading role in advancing sustainability in the future" (BSR/GlobeScan 2017) and this adoption of sustainability requires the rethinking and redevelopment of business strategies, products/services, processes, and resources (Silvius et al. 2012). Projects play an instrumental role in the sustainability strategies of organizations and thereby the sustainable development of society (Marcelino-Sádaba et al. 2015). Acknowledging the role projects play in developing towards sustainability, some authors suggested that the concepts of sustainability should also be integrated in the way a project management is executed and managed. Early publications on the integration of sustainability into project management include the works of Labuschagne and Brent (2005); Eid (2009); Maltzman and Shirley (2011) and Silvius et al. (2012). More recently, Silvius and Schipper (2014) and Aarseth et al. (2017) observed that the relationship between sustainability and project management is being addressed in a growing number of studies and publications and that today, "green" or "sustainable" project management is considered one of the most important global project management trends (Alvarez-Dionisi et al. 2016; Gemünden 2016).

In the publications about sustainability in project management, the topic of stakeholder management is frequently addressed (for example Eskerod and Huemann 2013; Bal et al. 2013; Labelle and Leyrie 2013). This may not be surprising as the consideration of stakeholders is well 
recognized within both the contexts of project management, for example in standards for project management such as the ISO 21500 (International Organisation for Standardisation 2012) and the PMBOK Guide (Project Management Institute 2017), and sustainable development (Jensen and Sandström 2011; Porter and Kramer 2011). However, Eskerod and Huemann (2013) observe that the standards of project management lack an explicit consideration of sustainable development principles and that "considering sustainable development as a context for projects, places new demands on project stakeholder management, especially when it comes to underpinning values". Integrating a sustainability perspective in project management implies a more holistic view of project stakeholder management (Huemann et al. 2016) and suggests a more open and proactive engagement of stakeholders (Silvius and Schipper 2014). "Specifically it calls for different values. Values like transparency and fairness constitute a management for stakeholder approach" (Huemann et al. 2016, p. XV). Labelle and Leyrie (2013) suggest a change in terminology from stakeholder management to stakepartner management to express this change in project management philosophy and practice.

Despite this conceptual understanding of the integration of sustainability into project stakeholder management, Marcelino-Sádaba et al. (2015) conclude that the literature still provides "little guidance [... ] on how to apply sustainability". Silvius (2019) adds that "Project managers in general do not have the time to 'translate' models and conceptual views into practical instruments" and concludes that it is therefore up to "authors, standards and researchers to 'package' the sustainability perspective in practically applicable tools, in order to change the behaviour of project managers". It is this need for instruments that this article aims to contribute to by studying how the concepts of sustainable development should be integrated in the frameworks used in the identification and analysis of project stakeholders, and developing practical tools for this. The remainder of the article is organized as follows. In the next paragraph, the concepts of project stakeholder management and sustainable development will be discussed based on their development in literature. Paragraph 3 describes the methodological approach that was applied in the study and develops the conceptual framework for the analysis. The following paragraph will describe the designed frameworks, structured in the processes of the planning of stakeholder engagement. The article will be concluded with a summary of its main contribution and a discussions of the limitations of the study.

\section{Background}

\subsection{Project Stakeholder Management}

\subsubsection{Recognition of a Stakeholder}

Project stakeholder management has its roots in the stakeholder theory of the firm, which emerged in the 1990s, following Freeman's book, Strategic Management: A Stakeholder Approach (1984). Stakeholder theory basically states that in order to be successful, an organization needs to take into account the interests of a wider group of stakeholders, including employees, customers, suppliers, etc., than just the interests of the shareholders (Freeman 1984). Although this appears to be a radical departure from the "shareholder value" thinking that dominated business decisions in the 1970s and 1980s, De Waal (2008) found that stakeholder value and shareholder value actually go hand in hand. If we interpret the consideration of stakeholder's interests also as ethical, these findings illustrate what Freeman (2008) call the "separation fallacy": the idea that business decisions and ethical decisions are in conflict with each other.

When considering the interests of stakeholders, a first decision that has to be made is to define who should be recognized as a stakeholders. Within the context of project management, this definition has evolved over the past decades. A contemporary perspective on stakeholders in project management is provided by the ISO 21500 standard, that defines a stakeholder as a "Person, group or organization that has interests in, or can affect, be affected by, or perceive itself to be affected by, any aspect of the project" (International Organisation for Standardisation 2012). Earlier perspectives were more restrictive in their recognition of stakeholders. The definition of Cleland (1985), "a stakeholder is an individual 
or organization with a (vested) interest in the project" (i.e. outcome, success), is often referred to as the first generation of project stakeholder definitions. Characteristic of this perspective is that the stakeholder needs to have a vested interest. Influenced by Freeman's stakeholder theory (Freeman 1984), a second generation of definitions developed. A definition of this second generation is "a stakeholder is an individual or organization that can affect or is affected by the project" (Boonstra 2006). This definition echoes Freeman's statement that a stakeholder is affected or can be affected. The impact of the organization or project has become optional. It is crucial as to whether the organization/project has the potential to impact the stakeholder. The third generation of project stakeholder definitions, as represented by the ISO 21500 definition, adds the element of perception. A stakeholder should be considered a stakeholder when he or she perceives himself/herself as (potentially) affected by the project. The factual impact of the project is not decisive, but the perceived impact.

The satisfaction of stakeholders with the project and/or its benefits is a recognized aspect of the success of a project (Albert et al. 2017). Project stakeholder management is therefore "a core activity of project management to gain project success" (Huemann et al. 2016).

\subsubsection{Project Stakeholder Management}

Project stakeholder management is often depicted as a set of process that relate to the different project management processes. For example the ISO 21500 standard identifies the process "identify stakeholders" as part of the initiating processes and the process "manage stakeholders" as part of the implementation processes. The PMBOK provides a more elaborated breakdown by distinguishing four processes: (1) identify stakeholders; (2) plan stakeholder engagement; (3) manage stakeholder engagement; and (4) monitor stakeholder engagement (Project Management Institute 2017). Stakeholder engagement is "the practice to determine and include stakeholder concerns, needs and values" (Erkul et al. 2016).

A more cyclical perspective is taken by Bal et al. (2013), who depict project stakeholder management as a continuous cycle of processes (Figure 1). In this model, the processes of project stakeholder management are: (1) identify key stakeholders and significant issues; (2) analyse and plan; (3) strengthen engagement capacities; (4) design the process and engage; and (5) act, review and report. There are three broad accompanying processes, these being "thinking and planning", "preparing and engaging" and "responding and measuring". Although this model emphasizes the continuous attention that should be given to stakeholder engagement during the project, it appears to be contradicting the temporary nature of projects.

The temporary nature implies that stakeholder engagement and relations are also dissolved at the closing of the project (Huemann and Zuchi 2014) for example with the goal to capture the knowledge that emerged in the relationship or to transfer the relationship to the permanent organization. Table 1 shows the overview of the project stakeholder management processes as Huemann and Zuchi (2014) identify them. 


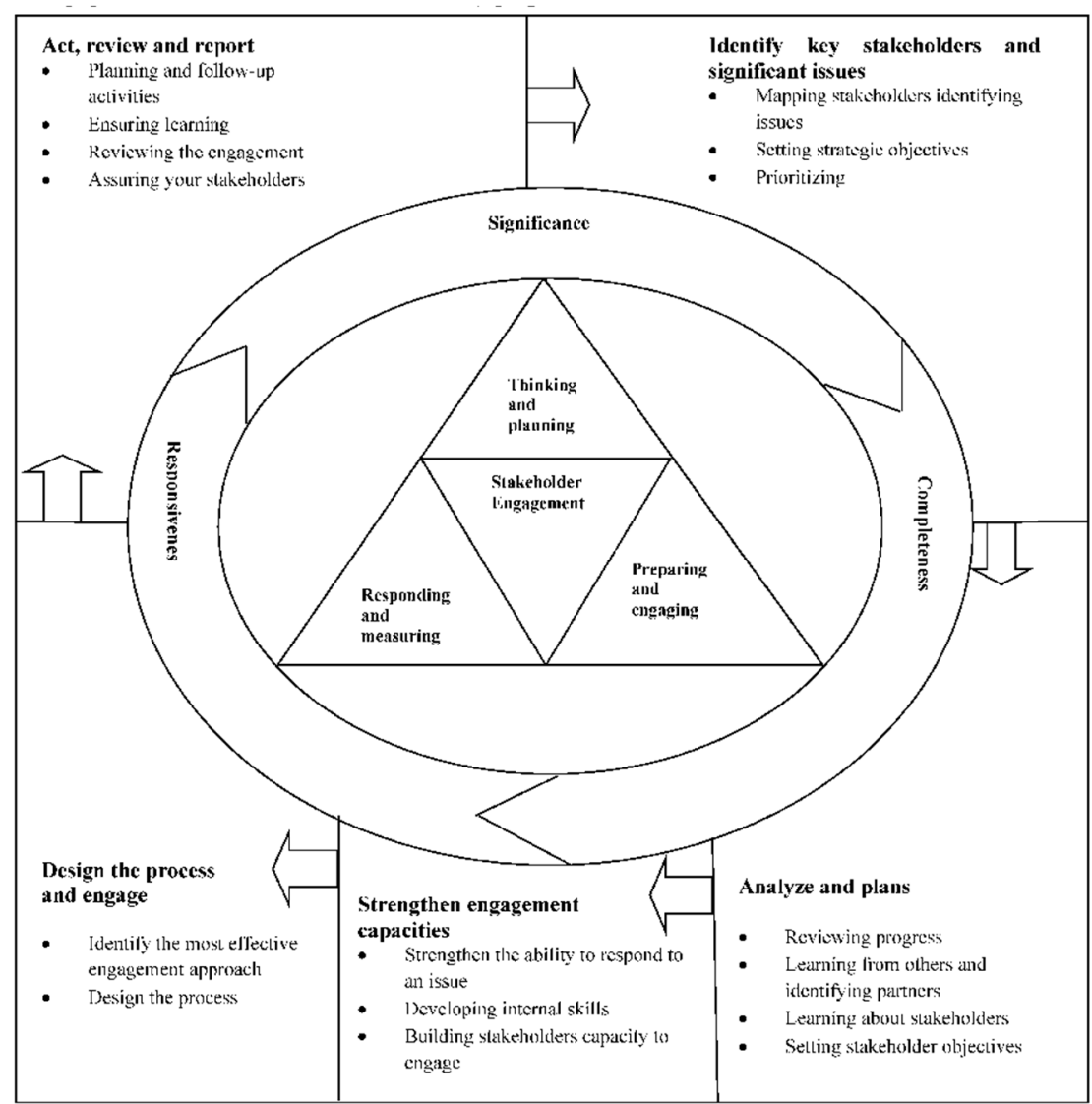

Figure 1. A process model of project stakeholder management (Bal et al. 2013).

Table 1. The stakeholder management process (Huemann and Zuchi 2014, pp. 394-95, edited).

\begin{tabular}{lllll}
\hline & $\begin{array}{l}\text { Starting up Project } \\
\text { Stakeholder } \\
\text { Relationships }\end{array}$ & $\begin{array}{l}\text { Managing Project } \\
\text { Stakeholder } \\
\text { Relationships }\end{array}$ & $\begin{array}{l}\text { Controlling Project } \\
\text { Stakeholder } \\
\text { Relationships }\end{array}$ & $\begin{array}{l}\text { Closing down Project } \\
\text { Stakeholder } \\
\text { Relationships }\end{array}$ \\
\hline $\begin{array}{l}\text { Relation to project } \\
\text { management }\end{array}$ & Project initiation & $\begin{array}{l}\text { Project marketing or part } \\
\text { of project coordination, } \\
\text { in some cases } \\
\text { comprehensive work } \\
\text { packages }\end{array}$ & $\begin{array}{l}\text { Project controlling or ad } \\
\text { hoc if there are any } \\
\text { potential conflicts }\end{array}$ & Project close down \\
Purpose & $\begin{array}{l}\text { Identifying stakeholders, } \\
\text { analysing their } \\
\text { expectations and } \\
\text { potential impacts, and } \\
\text { plan first engagement } \\
\text { activities. }\end{array}$ & $\begin{array}{l}\text { Performing stakeholder } \\
\text { engagement activities. } \\
\text { Different degrees of } \\
\text { engagement possible }\end{array}$ & $\begin{array}{l}\text { Controlling and } \\
\text { planning for redesigning } \\
\text { of stakeholder } \\
\text { relationships }\end{array}$ & $\begin{array}{l}\text { Final analysis of } \\
\text { stakeholder relation and } \\
\text { (emotional) close down } \\
\text { transferring } \\
\text { tranships } \\
\text { relationships to the } \\
\text { permanent organization }\end{array}$ \\
\hline
\end{tabular}

The article focuses on the planning processes of stakeholder management. More specifically, we will break down these planning processes into: "identifying stakeholders", "assessing stakeholders", and "planning stakeholder engagement activities". These processes correspond with the activities listed under "starting up stakeholder relationships" in Table 1 above. This focus is justified as the planning processes form the basis for the execution and controlling of engagement actions. Therefore, integrating the concepts of sustainable development into the planning of stakeholder engagement actions also affects the execution and controlling of these actions and thereby the whole stakeholder management process. 


\subsubsection{Management of Stakeholders vs. Management for Stakeholders}

Eskerod and Huemann (2013) conclude that the current standards of project management guide practitioners towards the recognition of a rather limited group of stakeholders and to "selling the project to the most important stakeholders rather than involving them and their interests into the creation of project objectives" (Eskerod and Huemann 2013, p. 43). Referring to Freeman's stakeholder theory (Freeman 1984), Huemann et al. (2016) differentiate between a "management OF stakeholders" approach and a "management FOR stakeholders" approach. In the management of stakeholders approach, stakeholders are seen primarily as providers of resources. The project needs the stakeholder to fulfil its purpose. The stakeholders are means and stakeholder management is the instrument used to make the stakeholders fulfil their role and prevent them from hindering the project.

In contrast, the management for stakeholders approach sees stakeholders as a source of ideas (Huemann and Zuchi 2014) and recognizes all stakeholders as having their own right and legitimacy (Julian et al. 2008). They are not defined by their role in the project, but by their interests. "Stakeholders are not means to specific aims in the organization but valuable in their own rights" (Eskerod and Huemann 2013, p. 40). This recognition implies that the orientation of the management of the project should be to shape the project in such a way that it combines the interests of many (all?) of the stakeholders and thereby provides value to many of them.

\subsection{Sustainable Development}

\subsubsection{Definition}

Concerns about the balance between economic growth, social wellbeing and the use of natural resources emerged as early as the 18th century (for example Von Carlowitz 1713; Malthus 1798). However, it took until the second half of the 20th century before the concerns about sustainability and sustainable development became broadly recognized as a political, societal and managerial challenge (Dyllick and Hockerts 2002). The 1972 book The Limits to Growth (Meadows et al. 1972) predicts that the exponential growth of world population and world economy will result in overshooting our planet's capacity of natural resources. Today, it is estimated that per year, our current society uses between 1.5 to 1.6 times the annual bio capacity of the earth (Toderoiu 2010), which is in the long-term not sustainable. Sustainable development can therefore be seen as the development of mankind and its use of the earth towards a more sustainable situation. The UN "World Commission on Development and Environment", named the Brundtland Commission after its chair, defined sustainable development as "development that meets the needs of the present without compromising the ability of future generations to meet their own needs" (World Commission on Environment and Development 1987).

By stating that "In its broadest sense, sustainable development strategy aims at promoting harmony among human beings and between humanity and nature", the Brundtland Commission implies that sustainable development includes a social and an environmental perspective, next to the economic perspective, on development and performance. The vision that societal goals, such as economic growth, social wellbeing, and a wise use of natural resources, are interrelated and that none of these goals cannot be realized without considering and affecting the other two, was widely accepted (Keating 1993). In his book Cannibals with Forks: the Triple Bottom Line of 21st Century Business, John Elkington identifies this as the "Triple Bottom Line" (TBL) concept: Sustainability is about the balance or harmony between economic sustainability, social sustainability and environmental sustainability (Elkington 1997).

The integration of sustainability considerations in companies and organizations, or "corporate sustainability", is defined by the Dow Jones Sustainability Indexes (2009) as "a business approach that creates long-term shareholder value by embracing opportunities and managing risks derived from economic, environmental and social developments". This definition highlights some of the concepts of sustainability that were also mentioned above: the triple bottom line (Elkington 1997) and the orientation in the long-term (Gareis et al. 2011), which is also referred to as a "life-cycle orientation" (Labuschagne 
and Brent 2005). The definition also highlights the element of risk, and its positive equivalent, opportunity. This balanced view on positive and negative effects of organizations can also be found in the definition of a sustainable enterprise by Van Tulder et al. (2014): "Where companies create value while not causing systematic harm to people and nature: they are engaged in sustainable enterprise or corporate (social) responsibility". This definition links corporate sustainability to the corporate social responsibility of an organization, as can also be found in the ISO definition of (corporate) social responsibility (International Organisation for Standardisation 2010). Although social responsibility has a more moral and ethical background, whereas the concepts of sustainability are more motivated from a systems thinking perspective, the typical social responsibility concepts of "stakeholder orientation", "accountability", "compliance" and "transparency" (International Organisation for Standardisation 2010) are nowadays also considered essential elements of corporate sustainability (De Loura and Dickinson 2016).

We therefore operationalize sustainable development in terms of four main concepts: triple bottom line, life-cycle orientation, stakeholder orientation, and responsibility, accountability and transparency. The next paragraph discusses these concepts in more detail.

\subsubsection{Concepts}

\section{Triple Bottom Line}

The Triple Bottom Line concept evolved into a set of perspectives for assessing, reporting or communicating the impact of human actions on nature. Several organizations have developed frameworks or sets of sustainable development indicators (SDIs) for this goal. However, this operationalization also introduces the risk that the interrelations between the three perspectives are overlooked and that the social, environmental and economic perspectives are each considered in isolation. A holistic understanding of the integration of economic, environmental and social perspectives is therefore considered one of the key-concepts of sustainability (Linnenluecke et al. 2009).

\section{Life-Cycle Orientation}

Dyllick and Hockerts (2002) conclude that sustainability is about consuming the income and not the capital. This aspect is a common realm in business from the economic perspective. However, from a social or environmental perspective, the impacts of human actions and behaviour may not be visible in the short-term. In order not to compromise "the ability of future generations to meet their needs", as stated in the Brundtland definition, sustainability requires a balance between both short and long term. This balance leads to a life-cycle orientation. Sustainability implies that "the natural capital remains intact. This means that the source and sink functions of the environment should not be degraded. Therefore, the extraction of renewable resources should not exceed the rate at which they are renewed, and the absorptive capacity of the environment to assimilate waste, should not be exceeded" (Gilbert et al. 1996).

\section{Stakeholder Orientation}

The International Institute for Sustainable Development elaborated on the Brundtland definition of sustainable development in a definition more focused on sustainable management of organizations: "Adopting business strategies and activities that meet the needs of the enterprise and its stakeholders today while protecting, sustaining and enhancing the human and natural resources that will be needed in the future" (Deloitte \& Touche 1992). From this definition, a clear relationship between sustainable development and stakeholder's interests appears. This relationship can also be found in the concepts of (Corporate) Social Responsibility (CSR) (Ebner and Baumgartner 2006). (C)SR is defined by the International Organisation for Standardisation as the "responsibility of an organisation for the impacts of its decisions and activities on society and the environment, through transparent and ethical behaviour that: contributes to sustainable development, including health and the welfare 
of society; takes into account the expectations of stakeholders; is in compliance with applicable law and consistent with international norms of behaviour; is integrated throughout the organisation and practiced in its relationships" (International Organisation for Standardisation 2010). A sustainable development of organizations therefore cannot be realized without an orientation on and consideration of stakeholder's interests.

Responsibility, Accountability and Transparency

The ISO 26000 definition of (C)SR also highlights the responsibility and accountability that an organization has for the societal impact of its decisions and actions, and the transparency and ethicality of its behaviour. This ethical dimension is an inseparable aspect of CSR (Dahlsrud 2008; Carroll 1991) and introduces a normative, values based, element. Sustainability is a value based concept, reflecting values and ethical considerations of society (Robinson 2004; Martens 2006). Its integration into business decisions and actions should go beyond being compliant with legal obligations. Carroll (1991) illustrated this in his seminal "Pyramid of CSR" model (Figure 2), by positioning the ethical responsibility of an organization separate from its legal responsibility. Dahlsrud (2008) therefore points out the voluntariness dimension of CSR.

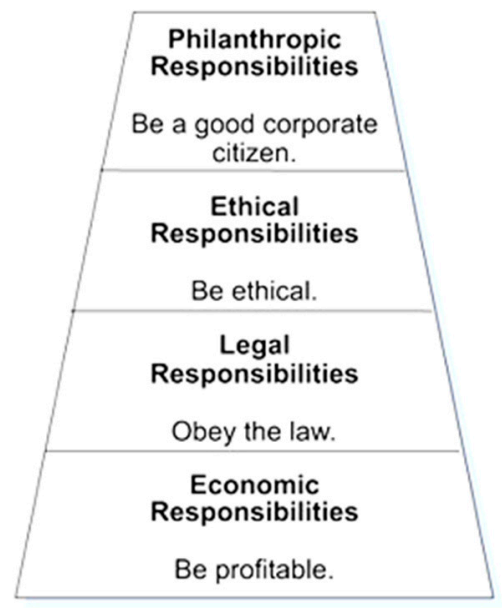

Figure 2. The Pyramid of Corporate Social Responsibility (CSR) model (Carroll 1991).

Carrolls pyramid model includes a philanthropic dimension. However, its position in the model expresses that philanthropy by organizations is seen as being less important than the other three components of CSR (Kakabadse et al. 2005).

\subsubsection{Sustainable Development and Project Management}

The above identified concepts of sustainable development impact on the way projects are executed and managed. For example, Maltzman and Shirley (2011); Silvius et al. (2012) and Tharp (2013) identify an impact of sustainability on project management in areas such as the identification of relevant stakeholders, the recognition of benefits, the assessment of risks and the organization of the project team. Based on a structured analysis of 164 publications on sustainability in project management, Silvius and Schipper (2014) conclude 14 "areas of impact", of which three directly relate to the topic of our study: project stakeholder management. Table 2 shows these project stakeholder management related impact areas. 
Table 2. Project stakeholder management related impact areas of sustainability on project management (derived from Silvius and Schipper 2014).

\begin{tabular}{|c|c|}
\hline Impact Area & Description \\
\hline $\begin{array}{l}\text { Identification of } \\
\text { stakeholders }\end{array}$ & $\begin{array}{l}\text { The concepts of sustainability increase the number of stakeholders of the project } \\
\text { (Tharp 2013; Eskerod and Huemann 2013) and bring new perspectives to the } \\
\text { project (AlWaer et al. 2008). Typical "sustainability stakeholders" may be } \\
\text { environmental protection pressure groups, human rights groups, } \\
\text { non-governmental organisations, etc. (Silvius et al. 2012). }\end{array}$ \\
\hline Project communication & $\begin{array}{l}\text { Following the principle of transparency and accountability, incorporating } \\
\text { sustainability into project management processes and practices would imply } \\
\text { proactive and open communication about the project, that would also cover } \\
\text { social and environmental effects, both short-term and long-term (Khalfan 2006; } \\
\text { Taylor 2010; Silvius et al. 2012). }\end{array}$ \\
\hline Stakeholder participation & $\begin{array}{l}\text { Several authors (for example Pade et al. 2008; Perrini and Tencati 2006) } \\
\text { emphasize the importance of stakeholder participation in projects. This } \\
\text { principle logically impacts the stakeholder management and the } \\
\text { communication processes in project management. However, the intention } \\
\text { behind "participation" goes beyond the process of stakeholder management } \\
\text { and communication. Stakeholder participation is not so much a specific process, } \\
\text { as it is an attitude with which all project management processes are performed } \\
\text { (Silvius and Schipper 2014). According to the ISO } 26000 \text { guideline, proactive } \\
\text { stakeholder engagement is one of the basic principles of sustainability } \\
\text { (International Organisation for Standardisation 2010). Stakeholder participation } \\
\text { requires "a process of dialogue and ultimately consensus-building of all } \\
\text { stakeholders as partners who together define the problems, design possible } \\
\text { solutions, collaborate to implement them, and monitor and evaluate the } \\
\text { outcome" (Goedknegt and Silvius 2012). Also, Eskerod and Huemann (2013) } \\
\text { link sustainable development, projects and the role of stakeholders, and } \\
\text { conclude that there is a need for "incorporating stakeholders and their interests } \\
\text { in more project management activities" (Eskerod and Huemann 2013, p. 45). }\end{array}$ \\
\hline
\end{tabular}

From these impact areas it can be concluded that the perspectives of sustainable development impact project stakeholder management, thereby confirming the need for practical instruments to operationalize this impact.

Based upon their review of published studies on the integration of sustainable development and project management, Silvius and Schipper (2014) also developed a definition of "sustainable project management": "Sustainable Project Management is the planning, monitoring and controlling of project delivery and support processes, with consideration of the environmental, economic and social aspects of the life-cycle of the project's resources, processes, deliverables and effects, aimed at realising benefits for stakeholders, and performed in a transparent, fair and ethical way that includes proactive stakeholder participation" (Silvius and Schipper 2014). In this definition, all four concepts of sustainable development (triple bottom line, life-cycle orientation, stakeholder orientation, and responsibility, accountability and transparency) can be recognized, as an addition to their description of project management ("planning, monitoring and controlling of project delivery and support processes" Silvius and Schipper 2014). In fact, the life-cycle concept is extended over the life-cycle of the project's resources, processes, deliverables, and effects. This extended life-cycle orientation is also shown from Silvius et al.'s (2017) visualization of the scope of sustainable project management (Figure 3). 


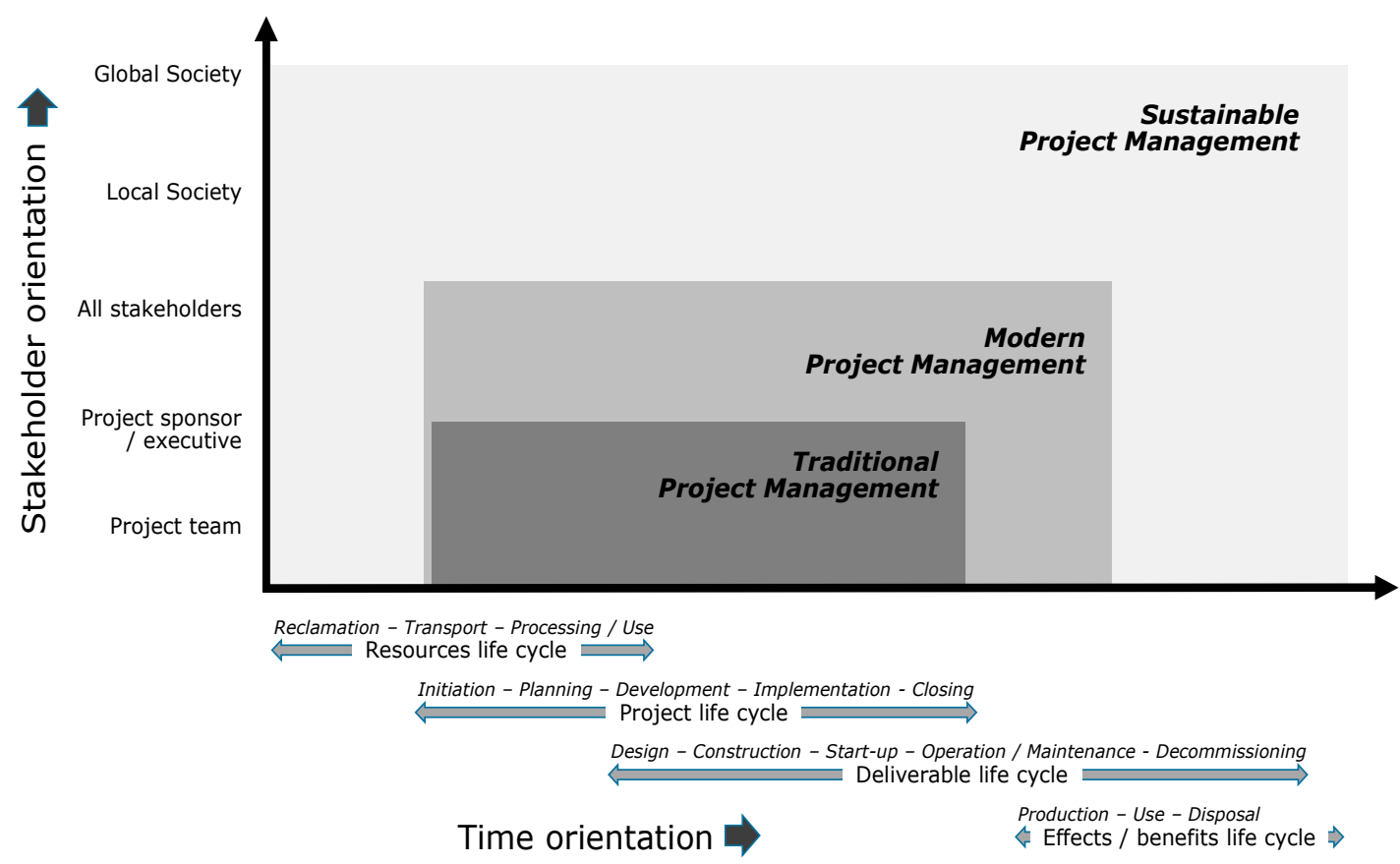

Figure 3. The scope of sustainable project management (Silvius et al. 2017).

In Figure 3, the scope of sustainable project management, is compared with that of "traditional project management", in which the scope of project management focuses on the project life-cycle, and "modern project management" in which the scope of project management includes also the use or operations phase of the deliverable of the project. The distinction between "traditional" and "modern" project management correspond with the different perspectives that Andersen (2008) identified.

In traditional project management, in Andersen's work identified as the "task perspective", projects are seen as "temporary endeavours" of carrying out given tasks (Andersen 2008). The project is ideally detached from the rest of the world and the project team should concentrate fully on carrying out the task. The role of the organizational context of the project is that of not interfering with the project. In this perspective, project management is focused on the planning and control processes within the project.

In what is now recognized as the Scandinavian School of project management, projects are considered from a more "organizational" perspective. In this perspective, a project is "a temporary organization, established by its base organization to carry out an assignment on its behalf" (Andersen 2008). In this "organizational perspective" on project, labelled as modern project management in Figure 3, the main purpose of a project is value creation in the base organization. As value creation comes with changes in that organization, a close cooperation between the base organization and the project is essential to the success of the project. In this perspective, project management is focused on the relationship between the permanent and the temporary organization.

Elaborating on the organizational perspective on projects and project management, sustainable project management positions the change and value that the project realizes in a societal context (Silvius 2017).

\section{Methodology}

\subsection{Approach}

The contribution this study aims to make is the development of practically usable frameworks for the identification and analysis of a project's stakeholder's interests, while taking into account the concepts of sustainable development. Based on the practical orientation of the aim of the study, we approached the study from a pragmatic perspective. The outputs of our study should therefore be 
judged on their "fit" with their purpose, identifying and analysing project stakeholder's interests, and their usability (Von Glasersfeld 2001), and not on their "truth" or "true explanation" as is common in studies using a positivist paradigm (Avenier 2010). In this we followed the numerous scholars, for example Cannella and Paetzold (1994), that pointed out the inadequacy of the positivist paradigm as a model for organization research. Pragmatism also fits the intention of stakeholder theory, as this aims to solve behavioural problems in the context of business (Freeman et al. 2018).

The study aims to help bridge the "relevance gap" between researchers and practitioners (Aram and Salipante 2003; Tranfield and Starkey 1998), by developing artefacts that can be used to solve the practical issue of how to integrate a sustainable development perspective in the identification and analysis of project stakeholders. This aim also positions the study as a design study. From a design science perspective, the main purpose of academic management research is to develop valid knowledge to support organizational problem solving in the field (Saunders et al. 2015). That support can be direct, instrumental or more indirect, giving general enlightenment on the type of problem at hand. A scientific perspective on design is provided by Simon (1996). Crucial in design science is that the artefact is designed according to an imperative or prescriptive logic. In this, methodological rigor is balanced with the demands of practical utility (Wieringa 2010). Design science research may therefore be seen as a paradigm rather than a discrete research methodology (Iivari 2007). Table 3 summarizes the most important characteristics of design science research (Baskerville et al. 2009)

Table 3. Characteristics of design science research.

\begin{tabular}{cc}
\hline Characteristic & Design Science Research \\
\hline Orientation & Research \\
Goal & Problem solving \\
Specificity & Generalized \\
Design role & Invention/Generative \\
Outcome & Design theory or Useful artifact \\
\hline
\end{tabular}

Pragmatism and organizational design science developed in parallel as alternative models of science well suited to the study of organizational phenomena (Avenier 2010). In the pragmatic research paradigm, acceptable knowledge can be derived from either or both observable phenomena and subjective meanings (Saunders et al. 2015). The study at hand used insights from organization design science to develop practically usable project management artefacts.

\subsection{Conceptual Analysis Framework}

The design logic of the study followed the following steps.

(1) Based on the literature the main variables of the study, sustainable development and the project stakeholder engagement processes are broken down into the concepts of sustainable development and the processes of planning stakeholder engagement. This step was reported in the Background paragraph.

(2) Based upon this breakdown of the main variables, a conceptual framework was developed (Figure 4) that depicts the analysis logic of the study. 


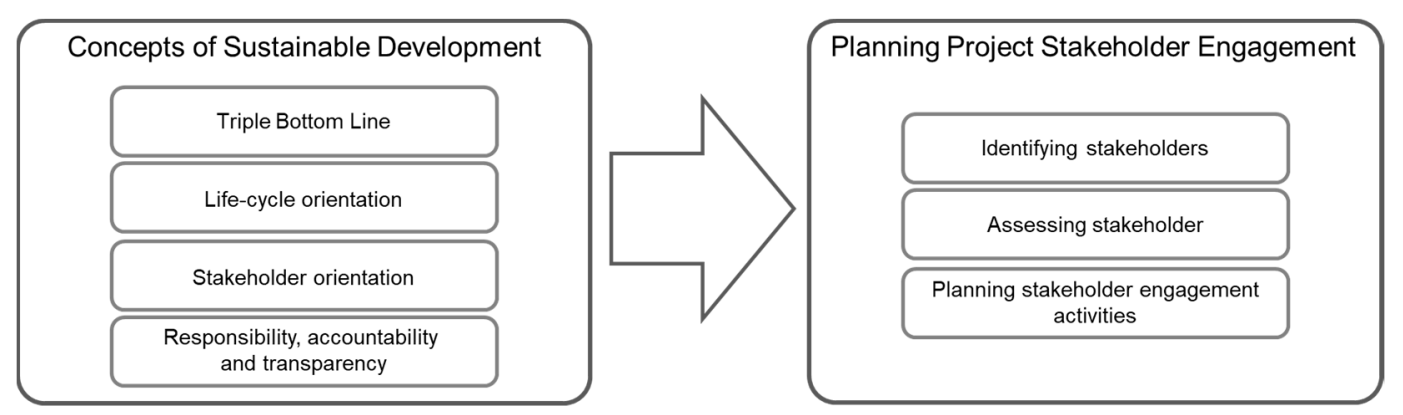

Figure 4. Conceptual framework of our analysis.

(3) Per process of planning stakeholder engagement, a set of question was derived from the four concepts of sustainable development, that could function as a list of requirements for the design and development of practical tools and frameworks for the execution of the stakeholder engagement planning processes.

(4) As per process of stakeholder engagement, the practices of these processes were derived from literature (professional standards and academic publications) that describe these practices. For the purpose of the study, these practices were labelled "documented practices".

(5) With this list of design requirements derived in step 3, the documented practices of the stakeholder engagement planning processes found in step 4 were reviewed, and a first version of tools and frameworks that integrate the sustainable development concepts were developed.

Based upon this conceptual analysis framework, step 3 of our design process derived, per process of planning stakeholder engagement, a number of questions that were derived from the concepts of sustainable development. Table 4 lists these questions.

Table 4. Questions about the planning project stakeholder engagement processes derived from the concepts of sustainable development.

\begin{tabular}{|c|c|c|}
\hline Process & Sustainable Development Concept & Questions \\
\hline \multirow{4}{*}{$\begin{array}{l}\text { Identifying } \\
\text { stakeholders }\end{array}$} & Triple bottom line & $\begin{array}{l}\text { Are also stakeholders that represent social and environmental } \\
\text { interests identified? }\end{array}$ \\
\hline & Life-cycle orientation & $\begin{array}{l}\text { Are also stakeholders that have interests in the use and } \\
\text { decommission phases of the project's deliverable identified? }\end{array}$ \\
\hline & Stakeholder orientation & $\begin{array}{l}\text { Are stakeholders identified from the perspective of the project } \\
\text { or the perspective of the stakeholder's interest? }\end{array}$ \\
\hline & $\begin{array}{l}\text { Responsibility, accountability and } \\
\text { transparency }\end{array}$ & Is the stakeholder identification done in a transparent way? \\
\hline \multirow{4}{*}{$\begin{array}{l}\text { Assessing } \\
\text { stakeholders }\end{array}$} & Triple bottom line & $\begin{array}{l}\text { Are the stakeholder's interests considered from all three } \\
\text { perspectives: economic, social and environmental? }\end{array}$ \\
\hline & Life-cycle orientation & $\begin{array}{l}\text { Are the stakeholder's interests related to the use and } \\
\text { decommission phases of the deliverable considered? }\end{array}$ \\
\hline & Stakeholder orientation & $\begin{array}{l}\text { Are the stakeholder's interests assessed from the perspective } \\
\text { of the project or the perspective of the stakeholders? }\end{array}$ \\
\hline & $\begin{array}{l}\text { Responsibility, accountability and } \\
\text { transparency }\end{array}$ & $\begin{array}{l}\text { Is the assessment of stakeholder's interest transparent to the } \\
\text { stakeholders? }\end{array}$ \\
\hline \multirow{4}{*}{$\begin{array}{l}\text { Planning } \\
\text { stakeholder } \\
\text { engagement } \\
\text { activities }\end{array}$} & Triple bottom line & $\begin{array}{l}\text { Are stakeholder engagement activities designed with } \\
\text { consideration of social (e.g., inclusiveness) and environmental } \\
\text { (e.g. energy use) aspects? }\end{array}$ \\
\hline & Life-cycle orientation & $\begin{array}{l}\text { Are the stakeholder relations and engagement activities at the } \\
\text { end of the project handed over to the permanent organization } \\
\text { in order to allow continuation during the use and } \\
\text { decommissioning phases? }\end{array}$ \\
\hline & Stakeholder orientation & $\begin{array}{l}\text { Are the engagement activities designed to fit the needs and } \\
\text { interests of the stakeholders? }\end{array}$ \\
\hline & $\begin{array}{l}\text { Responsibility, accountability and } \\
\text { transparency }\end{array}$ & $\begin{array}{l}\text { Are the engagement activities designed to enable and facilitate } \\
\text { an open communication with the stakeholders? }\end{array}$ \\
\hline
\end{tabular}

In step 4 of the design logic, the documented practices of the stakeholder engagement planning processes were derived from literature. In the final step of the design logic, step 5, the questions 
listed in Table 4 were used to review the documented practices of the stakeholder engagement planning processes, and as design requirements for the development of a first version of tools and frameworks that integrate the sustainable development concepts. This part of the study is reported in the next paragraph.

\section{Results}

\subsection{Sustainable Development and Identifying Stakeholders}

\subsubsection{Design Requirements}

The questions that were derived from the concepts of sustainable development for the Identifying stakeholders process were:

- Are also stakeholders that represent social and environmental interests identified?

- Are also stakeholders that have interests in the use and decommission phases of the project's deliverable identified?

- Are stakeholders identified from the perspective of the project or the perspective of the stakeholder's interest?

- Is the stakeholder identification done in a transparent way?

\subsubsection{Documented Practice}

The identification of stakeholders is usually described as a brainstorming activity (Bryson et al. 2011). Little structure is suggested for this brainstorm, although a more structured model for identification of stakeholders should be expected to enhance the completeness and quality of the identification. Freeman, in his initial work on stakeholder theory, recognized four groups of stakeholders as being important to the performance of an organization: customers, employees, shareholders and the public (Freeman 1984). Several authors elaborated on this first identification of stakeholders and developed a more elaborated framework for the identification of stakeholders, such as the stakeholder model (Figure 5) of the organization, developed by Donaldson and Preston (1995).

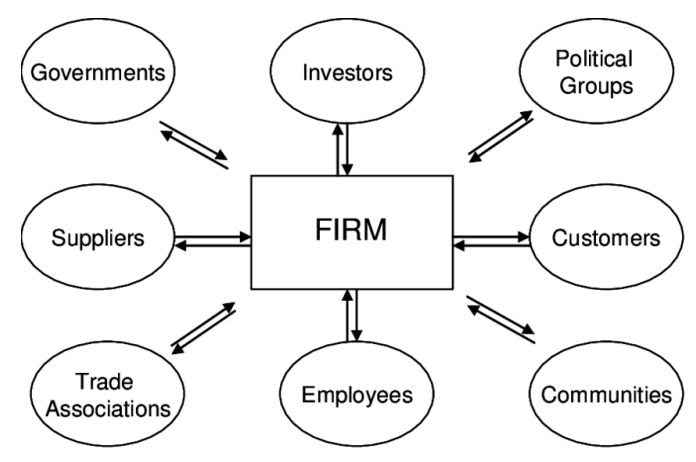

Figure 5. The stakeholder model (Donaldson and Preston 1995).

Based on an input-output view of the organization, the stakeholder model recognizes suppliers, customers, employees and investors as stakeholders that provide a direct contribution to the organization. The essence of the stakeholder model, however, is the recognition of groups that may not have a direct relationship with the organization, such as political groups, trade associations, communities and governments, as stakeholders.

In line with Freeman's stakeholder theory (Freeman 1984), the stakeholder model expresses that organizations can only be successful when they consider the interests of a wider group of stakeholders (Eskerod and Huemann 2013). By including the input-output relations that an organization has with suppliers and customers, the model also includes a partial orientation at the life-cycle or value chain of the organization's products, although the coverage of the life-cycle is incomplete. 


\subsubsection{Proposed Framework}

The stakeholder model provides a useful structure for a broader identification of stakeholders of the project, but does not comply with all questions that were derived from the concepts of sustainable development. For example the concepts of the triple bottom line and life-cycle orientation would require a framework that supports the identification of stakeholders throughout the life-cycles of project resources, activities, deliverables and effects, and from all three Triple Bottom Line perspectives. A first design for such a framework is presented in Table 5.

Table 5. Framework for a structured identification of stakeholders from a sustainable development perspective.

\begin{tabular}{|c|c|c|c|c|}
\hline & \multicolumn{4}{|c|}{ Life-Cycle } \\
\hline & $\begin{array}{l}\text { Resources } \\
\text { (extraction, transport, } \\
\text { processing) }\end{array}$ & $\begin{array}{l}\text { Project } \\
\text { (initiation, planning, } \\
\text { development, testing, } \\
\text { implementation, closing) }\end{array}$ & $\begin{array}{l}\text { Deliverable } \\
\text { (design, construction, } \\
\text { start-up, } \\
\text { operation/maintenance, } \\
\text { decommissioning) }\end{array}$ & $\begin{array}{l}\text { Effects/Benefits } \\
\text { (planning, generation, } \\
\text { disposal) }\end{array}$ \\
\hline $\begin{array}{l}\text { Stakeholders with } \\
\text { economic interests }\end{array}$ & $\begin{array}{ll}\text { - } & \text { Stakeholder A } \\
\text { - } & \text { Stakeholder B } \\
\text { - } & \ldots\end{array}$ & $\begin{array}{ll}\text { - } & \text { Stakeholder C } \\
\text { - } & \text { Stakeholder D } \\
\text { - } & \ldots\end{array}$ & $\begin{array}{ll}\text { - } & \text { Stakeholder E } \\
\text { - } & \text { Stakeholder F } \\
\text { - } & \ldots\end{array}$ & $\begin{array}{ll}\text { - } & \text { Stakeholder } \mathrm{G} \\
\text { - } & \text { Stakeholder } \mathrm{H} \\
\text { - } & \ldots\end{array}$ \\
\hline $\begin{array}{l}\text { Stakeholders with } \\
\text { social interests }\end{array}$ & $\begin{array}{ll}\text { - } & \text { Stakeholder I } \\
\text { - } & \text { Stakeholder J } \\
\text { - } & \ldots\end{array}$ & $\begin{array}{ll}\text { - } & \text { Stakeholder K } \\
\text { - } & \text { Stakeholder L } \\
\text { - } & \ldots\end{array}$ & $\begin{array}{ll}\text { - } & \text { Stakeholder M } \\
\text { - } & \text { Stakeholder N } \\
\text { - } & \ldots\end{array}$ & $\begin{array}{ll}\text { - } & \text { Stakeholder O } \\
\text { - } & \text { Stakeholder P } \\
\text { - } & \ldots\end{array}$ \\
\hline
\end{tabular}

The identification framework depicted in Figure 6 also allows to identify stakeholders by their interest, and not their role in the project, which was another requirement (Eskerod and Huemann 2013) and the third question we raised. The fourth question, "Is the stakeholder identification done in a transparent way?", is hard to cover in a framework, as it applies to the application of the framework rather than to the structure of the framework. It can be imagined that the project's identification and analysis of stakeholders is validated in feedback sessions with the respective stakeholder groups.

\subsection{Sustainable Development and Assessing Stakeholders}

\subsubsection{Design Requirements}

The questions that were derived from the concepts of sustainable development for the Assessing stakeholders process were:

- Are the stakeholder's interests considered from all three perspectives: economic, social, and environmental?

- Are the stakeholder's interests related to the use and decommission phases of the deliverable considered?

- Are the stakeholder's interests assessed from the perspective of the project or the perspective of the stakeholders?

- Is the assessment of stakeholder's interest transparent to the stakeholders?

\subsubsection{Documented Practice}

The assessment of stakeholders interests is usually done with graphical models (Murray-Webster and Simon 2006), such as the well-known "power/interest grid" (Figure 6, Eden and Ackermann 1998). 


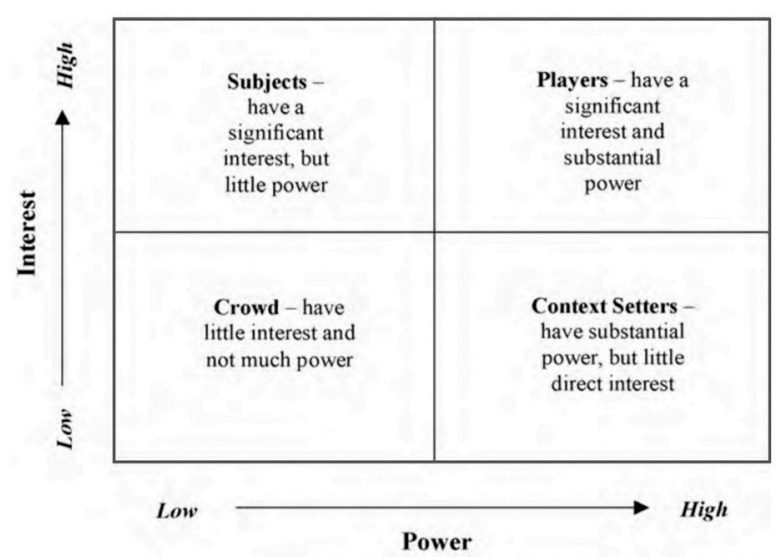

Figure 6. The power versus interest grid (Eden and Ackermann 1998, p. 122).

The power/interest grid provides a comprehensive overview of all stakeholder and supports the project manager in prioritizing stakeholder's interests and deciding the intensity of stakeholder engagement. It is considered a "best practice" method for planning project stakeholder engagement and included the PMI's PMBOK (Project Management Institute 2017). Despite this popularity, a number of limitations of the model can be pointed out.

- $\quad$ The power/interest grid is not suitable for identifying relations, interactions, and influences between stakeholders, as it focuses on the power/interest position of individual stakeholders.

- $\quad$ By ranking the different stakeholder's interests and power on an ordinal scale, the content of the interest is not visible and may be lost.

- The "interest" of a stakeholder may relate to different parts of the life-cycle of the project and its related resources, deliverables and benefits. The assessment of interest and a weak basis for the design of an engagement strategy.

From the perspective of sustainable development, a number of additional limitations can be observed.

- The "power" of a stakeholder is defined as the stakeholder's influence on the success of the project. This represents a strong inside-out perspective from the project to the stakeholder, which is not in line with the stakeholder theory inspired stakeholder orientation.

- The ranking of different stakeholders and the suggested prioritization make the stakeholder analysis a sensitive document that easily creates frustration or disappointed with the "lower ranked" stakeholders. The assessment step is therefore typically is "back room work" (Eden and Ackermann 1998) that lacks transparency.

The power/interest grid has also been expanded to a stakeholder "cube" by adding a third dimension: attitude (Bourne 2015). Although this refines the classification of stakeholders, the assessment of the attitude of a stakeholder may be problematic, as this attitude will largely be determined by the alignment of the project's objectives and stakeholder's interests, and the stakeholder analysis should also provide input for this alignment.

Another model for the analysis and classification of stakeholders is provided by Mitchell et al. (1997) (Figure 7). Their classification is based on the assessment of power, legitimacy and urgency of stakeholders, with the respective intersections of these three criteria. In this way seven, plus one for the stakeholders that cannot be classified within one or more of the criteria, classes of stakeholders can be identified. 


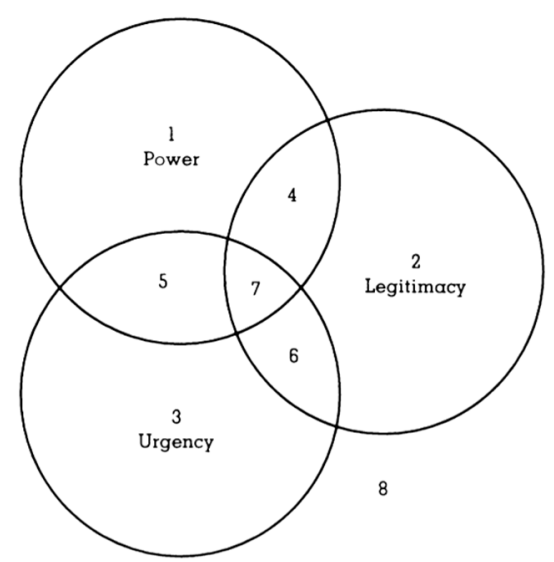

Figure 7. Stakeholder classification framework (Mitchell et al. 1997, p. 874).

The Mitchell et al. (1997) model can be considered a refinement of the power/interest grid, that provides a more elaborated insight in the stakeholders in order to select the suitable engagement strategy for each stakeholder (group). However, it also still includes some of the limitations that were also found in the power/interest grid. For example, it is also it is not suitable for showing relationships between stakeholders. From a sustainable development, the concept of the "legitimacy" of a stakeholder implies a "paternalistic" perspective on stakeholders that is not in line with the "partnership" perspective that stakeholder theory suggests (Labelle and Leyrie 2013). In a "management for stakeholders" approach, all stakeholders have the right and legitimacy to receive management attention (Julian et al. 2008).

As the integration of sustainable development principles in project stakeholder management is still a developing topic (Eskerod and Huemann 2013), inspiration for a suitable framework may also be found in the literature on stakeholder analysis within the context of corporate social responsibility. For example, based on the earlier discussed "Pyramid model" (Figure 2), Carroll (1991) developed a matrix model, the "Stakeholder responsibility matrix" (Figure 8), in order to identify and classify the interests of different groups of stakeholders on the different levels of the pyramid (Carroll 1991). Although our literature review did not reveal any studies that reported the use of the stakeholder/responsibility matrix in the context of project stakeholder management, the underlying "CSR pyramid" evolved as one of the most used models to analyse the CSR policies and practices of organizations (Slabá 2014; Ehie 2016).

\begin{tabular}{l|l|l|l|l} 
Stakeholders & Economic & Legal & Ethical & Philanthropic \\
\hline Owners & & & & \\
\hline Customers & & & & \\
\hline Employees & & & & \\
\hline Community & & & & \\
\hline Competitors & & & & \\
\hline Suppliers & & & & \\
\hline Social Activist Groups & & & & \\
\hline Public at Large & & & & \\
\hline Others & & & &
\end{tabular}

Figure 8. Stakeholder/responsibility matrix (Carroll 1991, p. 44).

The stakeholder/responsibility matrix takes a more text and content oriented approach, with less visualization of the priority or salience of the different stakeholders and/or interests. 


\subsubsection{Proposed Framework}

Overcoming the limitations of the power/interest grid would require a more content oriented approach to the interests of stakeholders, that is aimed at understanding what the relation of the stakeholder with the project is, instead of prioritizing stakeholders from the perspective of the project. A graphical analysis grid has qualities in providing a comprehensive overview, but may not be adequate for presenting more detail. We therefore propose the use of a table based framework, such as Carroll's model, but with a more developed structure. The proposed model is presented in Table 6. As an example, this table shows the interests of a fictitious "project owner" stakeholder.

Table 6. Proposed framework for analysing stakeholder's interests (with fictitious interests of a project owner stakeholder filled in as illustration).

\begin{tabular}{|c|c|c|c|c|c|}
\hline \multirow{2}{*}{ Stakeholder } & \multicolumn{4}{|c|}{ Anticipated Interests of the Stakeholder } & \multirow{2}{*}{$\begin{array}{l}\text { Expected Contribution of } \\
\text { the Stakeholder to the } \\
\text { Project }\end{array}$} \\
\hline & Object of Interest & $\begin{array}{l}\text { Level of } \\
\text { Interest }\end{array}$ & Content of Interest & $\begin{array}{l}\text { Type of Interest } \\
\text { (ec/soc/env) }\end{array}$ & \\
\hline \multirow{4}{*}{ Project Owner } & Project's resources & $\begin{array}{l}\text { Low } \\
\text { High }\end{array}$ & $\begin{array}{l}\text { Compliance with } \\
\text { applicable laws and } \\
\text { regulations } \\
\text { No bribery }\end{array}$ & $\begin{array}{l}\text { soc/env } \\
\text { soc/ec }\end{array}$ & \multirow{4}{*}{$\begin{array}{l}\text { Sufficient funding } \\
\text { Tolerance for uncertainty } \\
\text { and deviations from the } \\
\text { plan } \\
\text { Support } \\
\text { Trust in the project team }\end{array}$} \\
\hline & Project's processes & $\begin{array}{l}\text { High } \\
\text { Low }\end{array}$ & $\begin{array}{l}\text { Completion of the project } \\
\text { within budget and } \\
\text { schedule } \\
\text { Compliance with } \\
\text { applicable laws and } \\
\text { regulations } \\
\text { No accidents }\end{array}$ & $\begin{array}{l}\text { ec } \\
\text { soc/env } \\
\text { soc/env }\end{array}$ & \\
\hline & Project's deliverable & High & $\begin{array}{l}\text { Realization of a "fit for } \\
\text { use" deliverable }\end{array}$ & ec & \\
\hline & $\begin{array}{l}\text { Project's } \\
\text { effects/benefits }\end{array}$ & High & $\begin{array}{l}\text { Generation of expected } \\
\text { benefits }\end{array}$ & ec & \\
\hline \multirow{4}{*}{ N.. } & Project's resources & & & & \\
\hline & Project's process & & & & \\
\hline & Project's deliverable & & & & \\
\hline & $\begin{array}{l}\text { Project's } \\
\text { effects/benefits }\end{array}$ & & & & \\
\hline
\end{tabular}

In the framework depicted in Table 6, the main focus is on the interests of the stakeholders, rather than on the power of the stakeholders or their attitude towards the project. This is done in recognition that the attitude of stakeholders will largely be determined by the alignment of the project's objectives with their interests. Focusing on the content of a stakeholder's interest may therefore be more constructive than on its attitude. In order to get a more complete understanding of a stakeholder's interest, the different objects of its interest (resources, processes, deliverables and effects/benefits) are separately addressed. For every interest, the framework asks the user to classify the "level" or importance of this particular interest for the stakeholder (high/medium/low) and the type of interest (economic/social/environmental).

Following the example of Huemann et al. (2016), the framework also asks the used to specify what the project expects as contribution from the stakeholder to the project. This can be an active contribution (funding, resources, support, ideas, etc.) or a passive contribution (acceptance, tolerance, etc.). By explicitly listing the stakeholder's interest in the project and the project's interest in the stakeholder, the concept of "Management FOR stakeholders" is operationalized. In management for stakeholders, the relationship between the project and a stakeholder is seen as a balanced exchange of value and interests. The framework of Table 6 shows this exchange and therefore provides an elaborated foundation for the design and planning of stakeholder engagement actions.

The proposed framework also provides a foundation for more transparency in the stakeholder analysis. As the framework focuses on the content of stakeholder's interests, it should be easier to transparently reveal the analysis to the stakeholders and ask for their validation of the anticipated interests. 


\subsection{Sustainable Development and Planning Stakeholder Engagement Activities}

\subsubsection{Design Requirements}

The questions that were derived from the concepts of sustainable development for the Planning stakeholder engagement activities process were:

- Are stakeholder engagement activities designed with consideration of social (e.g., inclusiveness) and environmental (e.g., energy use) aspects?

- Are the stakeholder relations and engagement activities at the end of the project handed over to the permanent organization in order to allow continuation during the use and decommissioning phases?

- Are the engagement activities designed to fit the needs and interests of the stakeholders?

- Are the engagement activities designed to enable and facilitate an open communication with the stakeholders?

\subsubsection{Documented Practice}

In the planning stakeholder engagement process, the methods and actions to involve project stakeholders based on their needs, expectations, interests, and potential impact are determined (Project Management Institute 2017). The planned actions are documented in an actionable plan of efficient and effective stakeholder engagement activities that forms the basis for the execution, monitoring and controlling of these activities (ibid., p. 516). Methods and formats used in this plan usually follow a table format.

The planned stakeholder engagement activities provide input for the communication plan of the project (Project Management Institute 2017), however, stakeholder engagement can also be implemented in the project's organization or governance structures (Huemann and Zuchi 2014, pp. 394-95). For example by inviting stakeholders to participate in the project team, project board, steering committee, or advisory board.

Important is that the planned stakeholder engagement activities and methods fit the needs and interests of the stakeholders and enable an open and two-way communication with the stakeholders. "Two-way communication which provides a platform for information flow and stakeholder involvement is essential", conclude Erkul et al. (2016), as "The main purpose of engagement is to gain a transparent decision making process with greater input and feedback from stakeholders and their active support of the decisions which are made" (p. 706). Face-to-face communication in limited size settings with a facilitated communication may be the most preferred method for this, but the cost involved with organizing these activities and the barriers of location and availability of stakeholders call for also a creative use of (social) media and other communication channels. Sponselee (2016) concludes that the emergence of social media in communication provides an opportunity for project stakeholder engagement, as many social media channels enable two-way communication. However, in the same book, Silvius (2016) concludes that despite the opportunities social media provide, their use in stakeholder engagement is "lagging behind".

\subsubsection{Proposed Framework}

The planned stakeholder engagement actions can effectively be documented as an extension of the table used in the analysis of the stakeholder's interests. By adding columns for "Engagement strategy", "Engagement actions", and a reference to the corresponding activity in the Work Breakdown Structure ("WBS code") a transparent link between the stakeholder's relationship with the project and the designed engagement activities can be established. Table 7 shows this extended framework, again with the fictitious example stakeholder "project owner". 
Table 7. Proposed framework for analysing stakeholder's interests and documenting stakeholder engagement activities.

\begin{tabular}{|c|c|c|c|c|c|c|c|c|}
\hline \multirow[b]{2}{*}{ Stake-Holder } & \multicolumn{4}{|c|}{ Anticipated Interests of the Stakeholder } & \multirow{2}{*}{$\begin{array}{c}\text { Expected Contribution } \\
\text { of the Stakeholder to the } \\
\text { Project }\end{array}$} & \multirow[b]{2}{*}{$\begin{array}{l}\text { Engagement } \\
\text { Strategy }\end{array}$} & \multicolumn{2}{|c|}{ Engagement Action } \\
\hline & $\begin{array}{l}\text { Object of } \\
\text { Interest }\end{array}$ & $\begin{array}{l}\text { Level of } \\
\text { Interest } \\
(\mathrm{h} / \mathrm{m} / \mathrm{L})\end{array}$ & Content of Interest & $\begin{array}{l}\text { Type of Interest } \\
\text { (ec/soc/env) }\end{array}$ & & & Description & $\begin{array}{l}\text { WBS } \\
\text { Code }\end{array}$ \\
\hline \multirow{4}{*}{ Project Owner } & $\begin{array}{l}\text { Project's } \\
\text { resources }\end{array}$ & $\begin{array}{l}\text { low } \\
\text { high }\end{array}$ & $\begin{array}{c}\text { Compliance with applicable } \\
\text { laws and regulations } \\
\text { No bribery }\end{array}$ & $\begin{array}{l}\text { soc/env } \\
\text { soc/ec }\end{array}$ & Sufficient funding & \multirow{4}{*}{ Close cooperation } & $\begin{array}{c}\text { Bi-weekly informal status } \\
\text { updates }\end{array}$ & 1.3 \\
\hline & $\begin{array}{l}\text { Project's } \\
\text { processes }\end{array}$ & $\begin{array}{l}\text { high } \\
\text { low }\end{array}$ & $\begin{array}{c}\text { Completion of the project } \\
\text { within budget and schedule } \\
\text { Compliance with applicable } \\
\text { laws and regulations } \\
\text { No accidents }\end{array}$ & $\begin{array}{l}\text { ec } \\
\text { soc/env } \\
\text { soc/env }\end{array}$ & $\begin{array}{l}\text { Tolerance for uncertainty } \\
\text { and deviations from the } \\
\text { plan }\end{array}$ & & $\begin{array}{l}\text { Establishing WhatsApp } \\
\text { contact for questions and } \\
\text { short messages }\end{array}$ & 1.3 \\
\hline & $\begin{array}{l}\text { Project's } \\
\text { deliverable }\end{array}$ & high & $\begin{array}{l}\text { Realization of a 'fit for use' } \\
\text { deliverable }\end{array}$ & ec & Support & & $\begin{array}{l}\text { Monthly formal progress } \\
\text { report, followed by } \\
\text { project board meeting }\end{array}$ & 1.4 \\
\hline & $\begin{array}{c}\text { Project's } \\
\text { effects/benefits }\end{array}$ & high & $\begin{array}{l}\text { Generation of expected } \\
\text { benefits }\end{array}$ & ec & Trust in the project team & & $\begin{array}{l}\text { Exception reports when } \\
\text { necessary }\end{array}$ & 1.3 \\
\hline
\end{tabular}


Again, this framework can be transparently revealed to the stakeholders in order to validate the designed stakeholder engagement activities.

\section{Conclusions}

This article aimed to contribute to the integration of the concepts of sustainable development into project management by developing practical tools and frameworks that enable project managers to identify stakeholders, assess stakeholders, and plan stakeholder engagement activities with consideration of sustainable development. The study took a design science approach in developing these tools and frameworks after an analysis of the concepts of sustainable developments and a review of the documented practices of the processes of planning stakeholder engagement. The resulting frameworks therefore build upon the concepts of sustainable development and form an elaboration of the documented practice of project stakeholder management.

A limitation of the study and the resulting frameworks is that they are focused on the planning stakeholder engagement processes of project management. The integration with other methods, structures, and frameworks of project management was not included in the study. Another limitation is that the study did not include any empirical testing or evaluation of the developed frameworks. This is therefore a suggestion for further research and will be further developed by the authors at a later stage.

Author Contributions: Authors worked jointly on the conceptualization of the proposed frameworks. Literature background and methodology was provided by G.S.

Funding: This research received no external funding.

Conflicts of Interest: The authors declare no conflict of interest.

\section{References}

Aarseth, Wenche, Tuomas Ahola, Kirsi Aaltonen, Andreas Økland, and Bjørn Andersen. 2017. Project sustainability strategies: A systematic literature review. International Journal of Project Management 35: 1071-83. [CrossRef]

Albert, Matthias, Patrick Balve, and Konrad Spang. 2017. Evaluation of project success: A structured literature review. International Journal of Managing Projects in Business 10: 796-821. [CrossRef]

Alvarez-Dionisi, Luis Emilio, Rodney Turner, and Mitali Mittra. 2016. Global Project Management Trends. International Journal of Information Technology Project Management 7: 54-73. [CrossRef]

AlWaer, H., M. Sibley, and J. Lewis. 2008. Different Stakeholder Perceptions of Sustainability Assessment. Architectural Science Review 51: 48-59. [CrossRef]

Andersen, Erling S. 2008. Rethinking Project Management: An Organisational Perspective. Harlow: Prentice Hall.

Aram, John D., and Paul F. Salipante Jr. 2003. Bridging Scholarship in Management: Epistemological Reflections. British Journal of Management 14: 189-205. [CrossRef]

Avenier, Marie-José. 2010. Shaping a constructivist view of organizational design science. Organization Studies 31: 1-27. [CrossRef]

Bal, Menoka, David Bryde, Damian Fearon, and Edward Ochieng. 2013. Stakeholder Engagement: Achieving Sustainability in the Construction Sector. Sustainability 6: 695-710. [CrossRef]

Baskerville, Richard, Jan Pries-Heje, and John Venable. 2009. Soft Design Science Methodology. Paper presented at the 4th International Conference on Design Science Research in Information Systems and Technology, Malvern, PA, USA, May 9-20.

Boonstra, Albert. 2006. Interpreting an ERP-implementation project from a stakeholder next term perspective. International Journal of Project Management 24: 38-52. [CrossRef]

Bourne, Lynd A. 2015. For Stakeholders, 2×2 Is Not Enough! Available online: https://mosaicprojects.wordpress. com/2015/04/04/for-stakeholders-2x2-is-not-enough/ (accessed on 10 April 2019).

Bryson, John M., Michael Quinn Patton, and Ruth A. Bowman. 2011. Working with evaluation stakeholders: A rationale, step-wise approach and toolkit. Evaluation and Program Planning 34: 1-12. [CrossRef] 
BSR/GlobeScan. 2017. The State of Sustainable Business 2017; Results of the 9th Annual Survey of Sustainable Business Leaders. Available online: https://www.bsr.org/en/our-insights/report-view/bsr-globescansustainable-business-survey-2017 (accessed on 22 September 2018).

Cannella, Albert A., Jr., and Ramona L. Paetzold. 1994. Pfeffer's barriers to the advance of organizational science: A rejoinder. Academy of Management Review 19: 331-41. [CrossRef]

Carroll, Archie B. 1991. The Pyramid of Corporate Social Responsibility. Business Horizon 34: 39-48. [CrossRef]

Cleland, David I. 1985. A strategy for ongoing project evaluation. Project Management Journal 16: 11-17.

Dahlsrud, Alexander. 2008. How corporate social responsibility is defined: An analysis of 37 definitions. Corporate Social Responsibility and Environmental Management 15: 1-13. [CrossRef]

De Loura, Isabel Canto, and Robin Dickinson. 2016. Fractal Sustainability: A Systems Approach to Organizational Change. London: Routledge.

De Waal, Andre. 2008. The End of Shareholder Value Thinking. Business Strategy Series 9: 316-23. [CrossRef]

Deloitte \& Touche. 1992. Business Strategy for Sustainable Development: Leadership and Accountability for the 90 s. Winnipeg: International Institute for Sustainable Development.

Donaldson, Thomas, and Lee E. Preston. 1995. The stakeholder theory of the corporation: Concepts, evidence, and implications. Academy of Management Review 20: 65-91. [CrossRef]

Dow Jones Sustainability Indexes. 2009. Corporate Sustainability. Available online: http://www.sustainabilityindexes.com/07_htmle/sustainability/corpsustainability.html (accessed on 24 June 2019).

Dyllick, Thomas, and Kai Hockerts. 2002. Beyond the business case for corporate sustainability. Business Strategy and the Environment 11: 130-41. [CrossRef]

Ebner, Daniela, and Rupert J. Baumgartner. 2006. The Relationship between Sustainable Development and Corporate Social Responsibility. Available online: www.crrconference.org (accessed on 12 April 2013).

Eden, Colin, and Fran Ackermann. 1998. Making Strategy: The Journey of Strategic Management. London: Sage Publications.

Ehie, Ike C. 2016. Examining the corporate social responsibility orientation in developing countries: An empirical investigation of the Carroll's CSR pyramid. International Journal Business Governance and Ethics 11: 1-20. [CrossRef]

Eid, M. 2009. Sustainable Development E Project Management. Cologne: Lambert Academic Publishing.

Elkington, John. 1997. Cannibals with Forks: The Triple Bottom Line of 21st Century Business. Oxford: Capstone Publishing Ltc.

Erkul, Mehmet, Ibrahim Yitmen, and Tahir Çelik. 2016. Stakeholder Engagement in Mega Transport Infrastructure Projects. Procedia Engineering 161: 704-10. [CrossRef]

Eskerod, Pernille, and Martina Huemann. 2013. Sustainable development and project stakeholder management: What standards say. International Journal of Managing Projects in Business 6: 36-50. [CrossRef]

Freeman, R. Edward. 1984. Strategic Management: A Stakeholder Approach. Boston: Pitman/Ballinger.

Freeman, R. Edward. 2008. Managing for Stakeholders. In Ethical Issues in Business: A Philosophical Approach, 8th ed. Edited by Thomas Donaldson and Patricia Hogue Werhane. Englewood Cliffs: Prentice Hall, pp. 39-53.

Freeman, R. Edward, Robert Phillips, and Rajendra Sisodia. 2018. Tensions in stakeholder theory. Business $\mathcal{E}$ Society. [CrossRef]

Gareis, R., M. Huemann, R. A. Martinuzzi, M. Sedlacko, and C. Weninger. 2011. The SustPM Matrix: Relating sustainability principles to project assignment and project management. Paper Presented at the EURAM 11 Conference, Talinn, Estonia, June 1-4.

Gemünden, Hans Georg. 2016. From the Editor: Project Governance and Sustainability-Two Major Themes in Project Management Research and Practice. Project Management Journal 47: 3-6.

Gilbert, Richard, Don Stevenson, Herbert Girardet, and Richard Stren, eds. 1996. Making Cities Work: The Role of Local Authorities in the Urban Environment. London: Earthscan Publications Ltd.

Goedknegt, Debby, and A. J. G. Silvius. 2012. The implementation of sustainability principles in project management. Paper Present at the 26th IPMA World Congress, Crete, Greece, October 29-31; pp. 875-82.

Huemann, Martina, and Dagmar Zuchi. 2014. Towards a comprehensive project stakeholder management approach for HR projects. In The Art and Science of Managing Human Resource Projects. Edited by Richard J. Klimoski, Beverly Dugan, Carla Messikomer and Francois Chiocchio. Bowling Green: SIOP Practice Series.

Huemann, Martina, Pernille Eskerod, and Claudia Ringhofer. 2016. Rethinking Project Stakeholder Management. Newtown Square: Project Management Institute. 
Iivari, Juhani. 2007. A paradigmatic analysis of Information Systems as a design science. Scandinavian Journal of Information Systems 19: 39-63.

International Organisation for Standardisation. 2010. ISO 26000, Guidance on Social Responsibility. Geneva: International Organisation for Standardisation.

International Organisation for Standardisation. 2012. ISO 21500:2012, Guidance on Project Management. Geneva: International Organisation for Standardisation.

Jensen, Tommy, and Johan Sandström. 2011. Stakeholder theory and globalization: The challenges of power and responsibility. Organization Studies 32: 473-88. [CrossRef]

Julian, Scott D., Joseph C. Ofori-Dankwa, and Robert T. Justis. 2008. Understanding strategic responses to interest group pressures. Strategic Management Journal 29: 963-84. [CrossRef]

Kakabadse, Nada K., Cécile Rozuel, and Linda Lee-Davies. 2005. Corporate social responsibility and stakeholder approach: A conceptual review. International Journal of Business Governance and Ethics 1: 277-302. [CrossRef]

Keating, Michael. 1993. The Earth Summit's Agenda for Change. Geneva: Centre for our Common Future.

Khalfan, Malik M. A. 2006. Managing Sustainability within Construction Projects. Journal of Environmental Assessment Policy and Management 8: 41-60. [CrossRef]

Labelle, François, and Christophe Leyrie. 2013. Stakepartner Management in Projects. The Journal of Modern Project Management 1. Available online: https://www.journalmodernpm.com/index.php/jmpm/article/view/8 (accessed on 24 June 2019).

Labuschagne, Carin, and Alan C. Brent. 2005. Sustainable Project Life Cycle Management: the need to integrate life cycles in the manufacturing sector. International Journal of Project Management 23: 159-68. [CrossRef]

Linnenluecke, Martina K., Sally V. Russell, and Andrew Griffiths. 2009. Subcultures and sustainability practices: The impact on understanding corporate sustainability. Business Strategy and the Environment 18: 432-52. [CrossRef]

Malthus, Thomas Robert. 1798. An Essay on the Principle of Population. London: Reeves and Turner.

Maltzman, Richard, and David Shirley. 2011. Green Project Management. Boca Raton: CRC Press.

Marcelino-Sádaba, Sara, Luis Felipe González-Jaen, and Amaya Pérez-Ezcurdia. 2015. Using Project Management as a way to sustainability. From a comprehensive review to a framework definition. Journal of Cleaner Production 99: 1-16. [CrossRef]

Martens, Pim. 2006. Sustainability: Science or fiction? Sustainability: Science, Practice E Policy 2: 36-41.

Meadows, Donella H., Donella H. Meadows, Jørgen Randers, and William W. Behrens III. 1972. The Limits to Growth. Milford: Universe Books.

Mitchell, Ronald K., Bradley R. Agle, and Donna J. Wood. 1997. Toward a theory of stakeholder identification and salience: Defining the principle of who and what really counts. Academy of Management Review 22: 853-86. [CrossRef]

Murray-Webster, Ruth, and Peter Simon. 2006. Making Sense of Stakeholder Mapping. PM World Today 8: 1-5.

Pade, Caroline, Brenda Mallinson, and David Sewry. 2008. An Elaboration of Critical Success Factors for Rural ICT Project Sustainability in Developing Countries: Exploring the Dwesa Case. The Journal of Information Technology Case and Application 10: 32-55. [CrossRef]

Perrini, Francesco, and Antonio Tencati. 2006. Sustainability and Stakeholder Management: The Need for New Corporate Performance Evaluation and Reporting Systems. Business Strategy and the Environment 15: 286-308. [CrossRef]

Porter, Michael E., and Mark R. Kramer. 2011. Creating shared value. Harvard Business Review 89: 62-77.

Project Management Institute. 2017. A Guide to Project Management Body of Knowledge (PMBOK Guide), 6th ed. Newtown Square: Project Management Institute.

Robinson, John. 2004. Squaring the circle? Some thoughts on the idea of sustainable development. Ecological Economics 48: 369-84. [CrossRef]

Saunders, Mark, Philip Lewis, and Adrian Thornhill. 2015. Research Methods in Business Studies, 7th ed. London: Pearson Education Limited.

Silvius, Gilbert. 2016. Social Project Management. PM World Journal V: 1-11.

Silvius, Gilbert. 2017. Sustainability as a new school of thought in project management. Journal of Cleaner Production 166: 1479-93. [CrossRef]

Silvius, Gilbert. 2019. Making Sense of Sustainable Project Management. Annals of Social Sciences Management Studies 2: 555594. 
Silvius, A. J., and Ron P. J. Schipper. 2014. Sustainability in project management: A literature review and impact analysis. Social Business 4: 63-96. [CrossRef]

Silvius, Gilbert, R. O. N. Schipper, and Julia Planko. 2012. Sustainability in Project Management. Farnham: Gower Publishing.

Silvius, A. J. Gilbert, Martin Kampinga, Silvana Paniagua, and Herman Mooi. 2017. Considering Sustainability in Project Management Decision Making; An investigation using Q-methodology. International Journal of Project Management 35: 1133-50. [CrossRef]

Simon, Herbert A. 1996. The Science of the Artificial. Cambridge: MIT Press.

Slabá, Marie. 2014. Stakeholder Power-Interest Matrix and Stakeholder-Responsibility Matrix in Corporate Social Responsibility. Paper presented at the 8th International Days of Statistics and Economics, Prague, Czech Republic, September 5-7; pp. 1366-74.

Sponselee, Mark. 2016. Effects of social media on project management. In Strategic Integration of Social Media into Project Management Practice. Edited by Gilbert Silvius. Hershey: IGI Global, pp. 16-34.

Taylor, T. 2010. Sustainability Interventions-for Managers of Projects and Programmes. Salford: The Higher Education Academy-Centre for Education in the Built Environment.

Tharp, Jennifer. 2013. Sustainability in Project Management: Practical Applications. In Sustainability Integration for Effective Project Management. Edited by Gilbert Silvius and Jennifer Tharp. Hershey: IGI Global Publishing.

Toderoiu, Filon. 2010. Ecological footprint and biocapacity-methodology and regional and national dimensions. Agricultural Economics and Rural Development VII: 213-38.

Tranfield, David, and Ken Starkey. 1998. The Nature, Social Organization and Promotion of Management Research: Towards Policy. British Journal of Management 9: 341-53. [CrossRef]

Van Tulder, Rob, Rob Van Tilburg, Mara Francken, and Andrea Da Rosa. 2014. Managing the Transition to A Sustainable Enterprise: Lessons from Frontrunner Companies. London: Routledge.

Von Carlowitz, Hanns-Carl. 1713. Sylvicultura Oeconomica: Oder Haußwirthliche Nachricht und Naturmäßige Anweisung zur Wilden Baum-Zucht. Leipzig: Braun.

Von Glasersfeld, Ernst. 2001. The radical constructivists view on science. Foundations of Sciences 6: 31-43. [CrossRef]

Wieringa, Roel. 2010. Design science methodology: Principles and practice. In Proceedings of the 32nd ACM/IEEE International Conference on Software Engineering, ICSE '10. New York: ACM, Volume 2, pp. 493-94.

World Commission on Environment and Development. 1987. Our Common Future. Oxford: Oxford University Press.

(C) 2019 by the authors. Licensee MDPI, Basel, Switzerland. This article is an open access article distributed under the terms and conditions of the Creative Commons Attribution (CC BY) license (http://creativecommons.org/licenses/by/4.0/). 